\title{
A postmigrant contrapuntal reading of the refugee crisis and its discourse 'Foreigners out! Schlingensief's Container'
}

Marc Hill and Erol Yildiz

\section{Introduction}

When it comes to migration, the European Union is above all one thing, namely not united. Rather, predominant in the EU is a perspective that can be characterised as methodological nationalism. Refugees and especially asylum-seekers constitute one of the major points of contention between member states, and such persons are often represented in political debates and media reports as posing a threat to life in Europe. That was recently made clear inter alia in the controversy that erupted surrounding the signing of a symbolic UN document entitled "The Global Compact for Safe, Orderly and Regular Migration" (United Nations/General Assembly 2018) - in the event not all member states could bring themselves to agree to the compact. Likewise, recurrent negotiations arise regarding the numbers of refugees that the individual host countries should accept, and whether maximal limits should be instituted for how many refugees can be accorded entry in a given country. Furthermore, reportage about refugees and asylum-seekers, in the main media make use of the semantics of crisis; the upshot is that terms such as 'refugee crisis' and 'economic migrant' have been virtually inscribed into the collective popular memory. Given that the EU has the avowed aim of a just, peaceful and mobile Europe, viewed from a postmigrant perspective, the sheer dominance of border and security issues in discourse on refugees and the criminalised representation of refugees have come to constitute a problem for society as a whole.

Upon closer examination of this problem, we must ask: what might transpire if a social-critical perspective on refugees and asylum-seekers were to take root, and the general public were to be confronted with a counter-hegemonial corpus of knowledge and analysis? What alternative disturbing elements, fractures in attitude and conception, what manner of postmigrant readings would then emerge? The postmigrant lens in this context means a kind of contrapuntal 
way of thinking that would have a destabilising effect on established orders of knowledge and stimulate critical reflection. Such an epistemic approach directly interrogates conventional knowledge; it calls upon us to confront and re-examine everyday routinised practices. In the case of refugee flight and migration, it is a fact that countries in Europe are sealing themselves off from admitting refugees and migrants and that powerful deportation practices have become common and widespread. This article seeks to illumine this routine, reading it critically from a postmigrant vantage. ${ }^{1}$

In the quest for illustrative examples - in a European, and specifically an Austrian context - of how the powerful production of knowledge on refugees, their flight and asylum can be robustly challenged, we take note of a striking art action in Vienna, the much-discussed 'container action' by the German film and theatre director, author and performance artist Christoph Schlingensief, staged during the Vienna Festival (Wiener Festwochen) in 2000.

Fig. 5.1: Still from Ausländer raus! Schlingensiefs Container [Foreigners out! Schlingensief's Container]. Paul Poet, 2002.

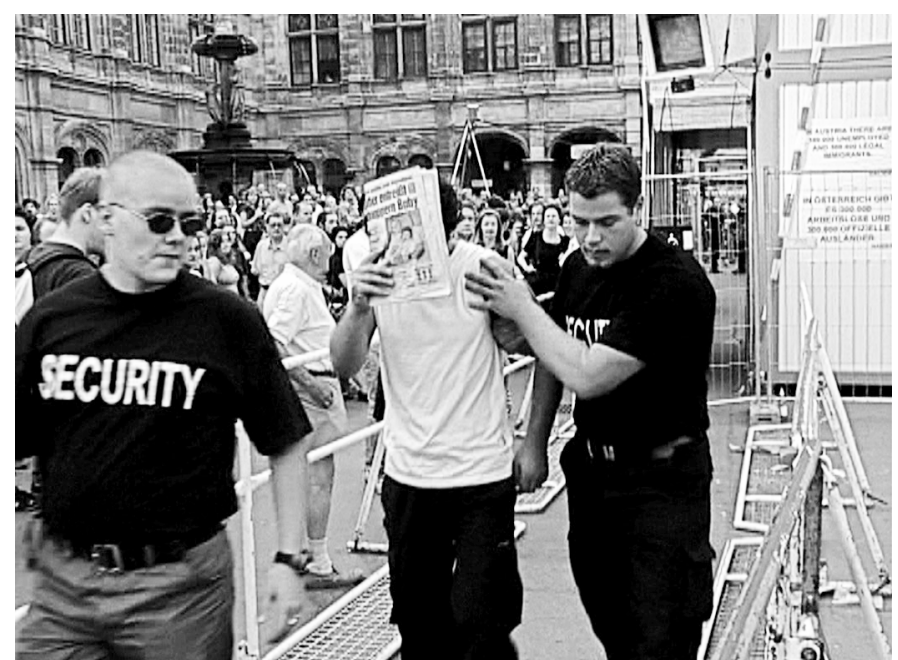

(c) Filmgalerie 451 and Paul Poet.

1 This chapter is a reworked version, incorporating the postmigrant perspective and translated into English, of a chapter "Europa in der Flüchtlingskrise? Schlingensiefs Container kontrapunktisch betrachtet" in the collective volume: Wiebke Sievers/Rainer Bauböck/Christoph Reinprecht (eds.), Flucht und Asyl - internationale und österreichische Perspektiven. Jahrbuch Migrationsforschung 5 , Vienna: Verlag der Österreichischen Akademie der Wissenschaften, 2021, Open Access. Translated from the German by Anna Galt and William Templer. 
In the art performance, Schlingensief confined twelve people in a container in front of the Vienna State Opera, where they assumed the role of refugees who had fled their home countries and were embroiled in a procedure of seeking asylum. They could be observed here both directly by passers-by as well an international public via livestream. In addition, the Austrian public was called upon to evaluate the asylum-seekers and deselect individuals among them for deportation, doing so according to the 'Big Brother principle' via telephone voting. This also took place live and in full public view. Not only were the prospective asylants inside the container and the passers-by thus integrated into the staging, the action also incorporated the entire cultural industry bound up with the Vienna Festival, sundry associated journalists, newspaper moguls and media-makers, politicians and onlookers across the world. Outsiders had no way of knowing whether those inside the container were actual bona fide refugees or simply actors. The persons inside were indeed real asylum-seekers, employed in the staging to play prospective asylants. Some years later, Paul Poet, a film director involved in the container performance, explained in interview exactly how the art action had been organised:

Setting up the container took scarcely any time to prepare. By contrast, what was time-consuming was the effort to find and engage genuine asylum-seekers, who were then hired on to play real asylum-seekers. In so doing, the Vienna Festival was operating on the very margins of legality, since they had engaged persons who were living in Austria in a sense 'submerged', employing them so they could work in the container performance. Fictive biographies were constructed to conceal their real biographies, although naturally there were real life stories behind them.

(Poet 2011, 461)

The Festival management even put up a sign explicitly stating that it was an art performance, i.e. a staging. Earlier on the performance had already caused huge outrage. The Austrian ambassador in France complained about the way in which the performance had been staged, since French businesspeople had interpreted it as something real rather than art. To mitigate the confusion, information leaflets in several languages were distributed. They stated: "This is a Wiener Festwochen art performance" (Lilienthal/Philipp 2000: 132).

The container performance thus drew its vital power from this blurring of boundaries between real life and art, between reality and fiction - a fact that was subsequently discussed in detail in the research literature. In her reconstruction of the events in Vienna, Catherina Gilles, a cultural studies scholar, noted for example: "What is true is what is probable, and sometimes art is more true than reality, because it shows what is true behind our self-constructed reality, even if we do not want to perceive it as true" (2009: 50). Schlingensief was consciously experimenting with this circumstance. 
This article will also refer repeatedly at points to this blurring of boundaries sketched above. It will be discussed in connection with public discourse on refugee flight and asylum, and the associated aspects of knowledge production and systems of order. Relevant theoretical points of reference are contained inter alia in Michel Foucault's reflections on discourse and the network-like connections within power-knowledge complexes (Foucault 1980). Based on Foucault, for example, the theatre studies scholar Ann-Christin Focke has investigated the different positions the individual was accorded in the container project - what roles were occupied by the "refugees" and the "public". In her Foucaultian analysis of the distribution of power in the performance, one of her conclusions is that the prospective asylants in the container appeared as a faceless collective, while the passers-by in the public repeatedly expressed a mindset operating with rigid ethnic stereotypes and national categories (2009:38-40).

The article's first section examines the dominant discourse on refugees and asylum from a postmigrant perspective. The characterisation of this as a 'dispositif' of asylum in the sense of Foucault's theory of power plays an important role here. In the second section, Schlingensief's art performance will be described in greater detail and interpreted as a rupture with this dispositif of asylum. Based on that, conclusions are drawn in particular for the further development of critical-reflective perspectives in research on migration and education.

\section{The postmigrant perspective: A different type of reading}

There are many different reasons why people leave their places of origin, seeking to secure their survival elsewhere. If nothing changes in the precarious living conditions in their countries of origin, becoming a refugee will continue to be a question of survival for many in the future. At the moment, political discussions in Europe centre mainly around possibilities for controlling the movement of refugees and border controls on one hand, and issues like participation, equality of opportunity and processes of empowerment on the other.

The current situation makes it clear that the European "fortress" mentality regarding immigration from non-European countries has left only very few routes open, and that the borders since the beginning of the new century have become ever tighter (Sassen 1996). Where options for immigrating in a regular way are in short supply, individuals harried and battered by war, persecution, hunger or poverty will endeavour to find new ways and strategies to migrate. Access to global mobility is one of the most important stratification factors of our current global society. In fact, a kind of global hierarchy of mobility exists (Bauman 1998).

At the same time, there is scarcely any discourse today that is so influenced by myths as the one on refugees. When people talk about refugees, they are often 
portrayed as a homogenous mass and imagined as so-called 'economic migrants' who will flood our society. In this context, there are often undertones that mark them as criminals, "as if it were tantamount to a crime when someone leaves their home in order to survive" (Haslinger 2016: 22). This de-individualising, generalising and criminalising view obscures the fact that these are individuals: human beings who have left their places of origin for various different reasons and who bring with them a whole range of differing backgrounds and experiences. In Europe they seek safety and a chance to build a new life.

In order to be able to see these persons in contemporary "Human Flow" (Ai Weiwei 2017) more clearly, their diverse experiences of migration and the new opportunities they seek, a transformed way of seeing them is required. In the last few years, the need for shifting the phenomenon 'refugees' and 'migration' from the periphery to the centre and viewing it as a significant asset for social development has been addressed particularly in approaches termed 'postmigrant'.

The postmigrant perspective presents and highlights the voice of migration, just as the postcolonial lets us hear the voice of the colonised. It renders visible marginalised forms of knowledge, serves to help destabilise national myths, reveals new understandings of differences and generates a new awareness of history. It therefore sees itself as a political perspective that also includes subverting and ironic practices, and in its reversal, it has a provocative impact on hegemonial conditions.

The history of migration and its consequences are retold anew, and different images, practices of representation and different ideas of subjectivity - in short, a different understanding of society - are generated. In the process, entrenched stablished views and concepts of order are deconstructed. In this context, Homi Bhabha refers to an "innovative disruption of our current world" (1994: XI). Binary constructions such as modern/traditional, Western/non-Western, foreigner/native become increasingly questionable.

Similar to postcolonial discourse, the prefix 'post' in postmigrant does not just denote the state of coming 'after' in a chronological sense. Rather, it is about a fresh retelling and re-interpretation of the phenomenon of 'migration' and its consequences.

Unlike the nationalist perspective, a postmigrant perspective means breaking with the customary prevalent discourses of migration and integration and rethinking the past. This rupture with the present, including a "conversion of one's gaze" (Bourdieu/Wacquant 1992: 251), means seeing and interpreting the world differently and formulating new ideas.

This way of looking has the potential to reveal new differences that make conventional conceptions of difference appear questionable. It represents a "radical revision of the social temporality" (Bhabha 1994: 246) and a "critical interruption into that whole grand historiographical narrative" (Hall 1996: 250). 
The conventional discourse on migration describes migration stories as specific exceptional historical phenomena and makes a distinction between developments in the countries of origin and host countries, between indigenous local normality and immigrated problems. In this way, certain constructions such as 'dominant culture', 'integration' and 'foreign mentality' have become established and normalised.

However, today's global situation demands the radical questioning of the conventional view of migration and so-called Western values and opens up new perspectives on the world (Beck 2017). Those new global processes of opening up point to other local practices of positioning, facilitate new kinds of readings and require a different understanding of the world. It is precisely through migratory movements that new social constellations, traditions and creative life plans are created that do not fit in with and conform to common norms.

\section{The public sphere and discourse}

When one takes a look at current discourse, at reports, assessments and analyses of the situation of refugees and migrants in Austria and Germany, three patterns of interpretation are notable that channel public perception and both shape and reflect the prevailing mood:

First, the current situation is dramatised in an ahistorical fashion-it seems to appear as if our societies are being confronted with the issue of refugees for the first time and therefore are overstretched, largely unable to handle the influx (Althans et al. 2019: 7-9). But it is precisely Austria and Germany in particular which have already dealt with several 'refugee crises' in their recent history: after the Second World War, before and after the fall of the Iron Curtain and during the wars in former Yugoslavia. Yet the current discourse barely mentions these experiences, which - as history itself shows - did not lead by any means to the disintegration of the host society due to refugee influx, but rather should be evaluated as largely successful (Ette 2017).

Second, public controversies are often triggered with the help of sensationalist imagery. This also calls to mind the multitude of nature metaphors with which the movement of migrants and refugees is almost automatically described in postmigrant societies: 'currents', 'waves', 'floods', 'dam burst', 'deluge', 'influx', etc. These terms shape the perception of refugees in public discourse (Friese 2017). The focus is on scandalising and sensationalising refugees, human flows, their temporary camps, overcrowded boats and large halls where they are herded together. These one-sided images reinforce the impression that Europe must robustly protect itself from refugees in order to confront and tackle the 'crisis'. The welcoming attitude towards refugees -observable in large segments of the population in many 
Western European countries, especially in September 2015 and the months thereafter - has now morphed, increasingly pervaded by security concerns. Within the media, there is a mounting tendency toward de-subjectification of refugees and asylum seekers: all we see is persons en masse - not individual human beings.

Third, in the meantime within the political discourse of the European Union, the distinction between "genuine" and "fake" refugees (Scherr 2017: 91) is often viewed as part of the solution. The term 'economic migrants' suggests an illegitimate desire for comfort and luxury. Over against that stands a distressing fact: the multitudes of persons who flee their countries do so because their lives and safety are under threat, as the annual reports of the United Nations High Commissioner for Refugees (UNHCR) substantiate. At the end of 2017, the number of those worldwide deemed persecuted because of conflicts or violence amounted to 68.5 million (UNHCR 2018: 2). However, that same year, only about 650,000 persons applied for asylum in the European Union (EU) (Eurostat 2018). Thus, compared to the number of human beings in acute danger, the number of applications filed in the EU is relatively low. Moreover, with regard to the supposed abuse of asylum law in the EU by "economic migrants", rarely mentioned is how many millions of Europeans themselves have departed their home countries for economic reasons in search of a new life overseas - or migrated even to save their own lives, at home at risk.

Not least, it is important to note that these three interpretative patterns regarding refugees and asylum-seekers sketched above also impact on ever new demands for integration. In many cases, refugees are currently viewed either as needy victims (victim discourse) or hostile foreigners (threat discourse) who will 'flood' the country. In this connection, Zygmunt Bauman writes that "all societies produce strangers; but each kind of society produces its own kind of strangers, and produces them in its own inimitable way" (1997: 17). This statement points to nationally focused ideologies, to the power of certain interpretations, through which individuals who have crossed borders become Others, become strangers, who must be investigated and understood, warded off and controlled, utilised and integrated. Hence, we see in public discourse the construction of a mythologem of difference, which in turn is then naturalised. Thus, media reports, political debates and sometimes scientific papers as well give the impression that being a "refugee" is a characteristic of a person: by using "refugee" as a social category, the fact that it is a basic legal category is excluded or ignored. The sociologist Katharina Inhetveen also investigates the social figure of "the refugee":

In wealthy Western counties, the figure of the refugee is unthinkable without the suspicion that he or she might not be a refugee at all. The refugee can hardly shake off the suspicion of 'asylum fraud'. Do they come from a poor country? - They probably just want to live in prosperity and are not really escaping persecution 
and violence at all. He or she does not have any papers? They probably just want to make it more difficult to deport them. In Europe the refugee becomes an 'asylum-seeker', not someone who is seeking refuge, but rather a person who wants to obtain better living conditions, illegally, illegitimately and deviously. (Inhetveen 2010: 154-155)

This quote makes it clear: in public discourse, a person does not become a refugee because of the personal decision to leave the place they are from, but by crossing national borders on the one hand, and through legal norms and institutional practices in the host country on the other. These kinds of classifications have far-reaching effects that construct realities and generate certain frames for reality perception. Without question, the media also have a significant influence on the social imaging of refugees and people who have fled their homes and homelands.

Contrasting with attempts to present more differentiated images and representations of refugees, mass media reportage appears in many cases to have long since become a kind of campaign with an agenda, especially in terms of the imagery and figurative language. In visual terms, an effect emerges that is in part strikingly threatening, menacing, in part it appears even more often in motifs more subtle. Media reports often exacerbate public debates: movements of refugees in flight are portrayed with excessive exaggeration, the Otherness of the refugees and newcomers is often presented absurdly as something 'degenerate', sensationalised stories and a specific focus on scandalous aspects are superimposed on everyday life, shaping reports and position statements (Yildiz 2006).

Such patterns of interpretation amount to a de-contextualising of the practices and experiences of refugees and migrants. They function to exclude social power relations on one hand, and the diverse plurality, ambivalence and complexity of their lifestyles and orientations on the other. It is precisely ambivalence and the attachment to "multiple homes" (das Mehrheimische), a sense of hybrid identity, that are a central element of postmigrant societies. However, this is largely marginalised, ignored and excluded by the hegemonial tenor of refugee discourse. In discourse about migration, the idea repeatedly surfaces that migrants are in cultural terms ambivalent, divided, torn between two poles of identification. In this context, the sociologist Robert E. Park already spoke about life as a "marginal man" (Park 1928). In the meantime, the metaphor of life 'caught between two stools' or 'in-between' has established itself in everyday understanding and language. What is signified here in cognitive and emotional terms is a presumably interior conflict that migrants must cope with, since they are living in another country, with another culture, and as a result become Outsiders. Park even characterises this condition as a threat to mental health, one which could trigger depression.

The condition of being 'in-between' is thus viewed as problematic from a cultural and national vantage, but on closer scrutiny this perspective turns out to be 
overly determinative and stigmatising by dint of its pathologising features and territorial and culturalising orientation. Yet in many respects this hybrid in-between' harbours the possibility to deal creatively with challenges, to develop an innovative social praxis, thus opening up spaces for one's own individuality. For that reason, categories of national origin are only seemingly analytical and need to be robustly interrogated. In reality their effect is rather to (re)produce reality, to guide our perception of reality, and in this way ultimately impact once again on society. At the same time, they blanket out and thus obscure our perception and vision of the actual complexity of real life.

To disrupt this logic, a different way of approaching the subject is required - a "contrapuntal reading", as Edward Said has proposed for analysing images of the "Orient" and "Occident", and at the same time destabilising them (Said 1994: 66). His idea is to read anew and differently the "cultural archive" (ibid.: 51), which is based on Western hegemony. As a literary scholar, his interest lay in the conventional formation of Euro-American "high culture":

We must therefore read the great canonical texts, and perhaps also the entire archive of modern and pre-modern European and American culture, with an effort to draw out, extend, give emphasis and voice to what is silent and marginally present or ideologically represented [...] in such works. (Ibid.: 66)

In our view, the contrapuntal reading of canonical texts that Edward Said proposes can also be applied to public discourse on refugees and migrants. In it, the experiences and perspective of people who have fled their homes and are trying, under difficult social conditions, to find ways/detours/unusual pathways to live or survive, are often left out. In this context, contrapuntal thinking means taking a new look at the historical and current developments, where what is marginalised and what goes untold is taken as the starting point. But contrapuntal thinking also means consolidating thinking about restrictive living conditions and migration regimes on one hand, as well as strategies for action and self-empowerment on the other. This new mode of reading is also required in academic and scientific discourse - even here the personal knowledge of refugees and migrants has scarcely been dealt with as a thematic focus. One such exception is Louis Henri Seukwa's Der Habitus der Überlebenskunst (The Habitus of the Art of Survival, 2006); he sought to utilise and interpret refugees' experiential knowledge. Currently, this contrapuntal perspective is also employed in the new collective volume edited by Birgit Althans and colleagues Flucht und Heimat (Escape and Home, 2019).

Taking the experiences and perceptions of refugees and migrants as the starting point means viewing them as active subjects with agency and recognising them as experts on their own life practice, who are confronted with social patterns and challenges, and who create their own plans for living and spaces for ac- 
tion within them. This kind of counter-reading means rethinking the hegemonial discourse on asylum from the perspective of refugees, recognising and using their background of experience as a point of departure. Not only is hegemonial normality deconstructed in doing so: perspectives on marginalised, not yet told stories and everyday experiences are also opened up in the process (Hess 2015:49-51).

\section{The standardising power of the asylum dispositif}

That refugees are human beings just like everyone else, with certain skills, strengths, resources, but also beset by problems, is not visible in either the discourse of victimisation or the discourse of threat. Instead, their existence is reduced to social problems and conflicts, which are often stylised as unresolvable obstacles to integration. The refugee thus gradually embodies the non-national Other, the stranger - and correspondingly, the obstacles to integration seem to continuously grow. These historically constructed orders of knowledge and power relations that continue to be reproduced in the present can be called a dispositif in Foucault's sense (1978). He understands dispositif as a

[...] heterogeneous ensemble that includes discourses, institutions, architectural forms, regulatory decisions, laws, administrative measures, scientific statements, philosophical, moral and philanthropic propositions - in short, the said as much as the unsaid. (Foucault 1980: 194)

The value of using this term lies in its incompleteness and therefore transferability in terms of the theory of power to socially relevant events that are discussed intensively in the public sphere and have a certain influence on institutional realities. Foucault can be used to show how public discourse about refugees comes into being (discursive formation), how a certain (prescribed) knowledge is disseminated by scientists and scholars, the media, politics, etc., and how this interpretative knowledge produces a normality that functions to channel and direct perception in institutions und everyday communications, a kind of implicit knowledge that is barely reflected upon. This interpretive knowledge also partly determines the interaction between refugees and the local population. The fact that "being a refugee" is seen as an unalterable characteristic of a person can only be understood in relation to this hegemonial discourse.

Louis Henri Seukwa also refers to Foucault when in an interview he uses the term "asylum dispositif". He employs it to address the link between restrictive asylum legislation, discriminating institutional practices and negative social constructions, which dominate public discourse on refugees and accompany their everyday experience of discrimination (Seukwa 2015). This is a huge challenge for 
those concerned: only individuals with a special ability to resist and capacity to act can overcome it. Seukwa calls this specific ability "the habitus of the art of survival" (Habitus der Überlebenskunst), likewise the title of his book (2006). The concept has recently been discussed anew in social-pedagogical discourses under the heading "agency" (Hill 2019).

The asylum dispositif, which this article focuses on, implies a network of practices, institutional mechanisms, actions and discourses that over time have become a dominant pattern of explanation and a specific practice of representing social reality. The term thereby describes a certain type of power that is exercised over refugees, a knowledge that is produced about them. Stuart Hall writes: "Those who produce the discourse therefore have the power to make it true - i.e. to enforce its validity, its scientific status" (1992: 294). With such an interpretive knowledge in the treatment of refugees, it is therefore not just about personal attitudes or judgements, but about social bodies of knowledge, an order of knowledge, which produces a certain group in the first place or makes it visible and then identifies it as a source of conflict (Terkessidis 2004). This kind of objectification of the supposed other has a normalising effect that reaches deep into everyday praxis: social problems are automatically identified as ethnic cultural problems, and the refugees appear potentially criminal, needing therapy, or repair, to "be made a patient is to be remade into a serviceable object" (Goffman 1961: 379). The epistemological basis of this kind of prescribed knowledge is a homogenous Austrian or German society, which must find the appropriate way to deal with these Others. Like a self-fulfilling prophecy, this generalising focus on social problems ultimately engenders its own reality and forms the basis for further interventions.

This perspective ignores how the refugees see and position themselves, which elements of self-identification they utilise in those positionings, what types of life-constructions they explore, in what ways they tackle the social conditions (objective possibilities) they live in and how they find their own life paths (subjective possibilities). Cultural, ethnic or national categories that turn humans into "refugees" - thereby reducing them to a special status - ignore the contexts in which strategies for survival are developed.

Such social constructions may be symbolic structures acting as discursive effects, which become fixed as ideological constructs in people's minds. But above all, in reference to the thinking of Pierre Bourdieu, they should be viewed as a social praxis that involves many actors and institutions of power (Bourdieu 1987: 163). "Being a refugee" is not a natural characteristic, but is embedded in multiple ways in social structures and institutional practices; and precisely because it is a social praxis with which actors permanently produce and reproduce, the distinction "us and the others" or "refugee"/"non-refugee" seems to be such a stable category of classification. The actors appear to have only limited awareness of these everyday practices. They function mainly as routines that only become evident when "dis- 
turbances" occur, when unexpected or unfamiliar interactions force the participants to reflect on their actions. Anyone who wants to develop new perspectives and options for action must always bear this social praxis in mind.

\section{Schlingensief's container performance}

If we take a look at the current situation in the EU, it becomes clear that 'maximum limits on the numbers' of refugees who are allowed to enter the country, border controls and the rejection of 'welcome culture' are the dominating topics. In the age of migration and globalisation, the fears associated with these topics are just as scarcely a new phenomenon as are the experiences of flight from one's homeland. Recently, in the 1990s, it was persons from former Yugoslavia who fled to Austria, Germany and other European countries. At that juncture, the Austrian politician Jörg Haider - governor of the state of Kärnten 1989-91 and 1999 until his death in 2008 - garnered a lot of media attention with his restrictive refugee policy (Ottomeyer 2009). When a coalition government was formed in 2000 on the federal level between the ÖVP (Austrian People's Party) and the FPÖ (Liberal Party of Austria), this political shift to the right in the heart of Europe sparked substantial international controversy.

Fig. 5.2: Still from Ausländer raus! Schlingensiefs Container [Foreigners out! Schlingensief's Container]. Paul Poet, 2002.

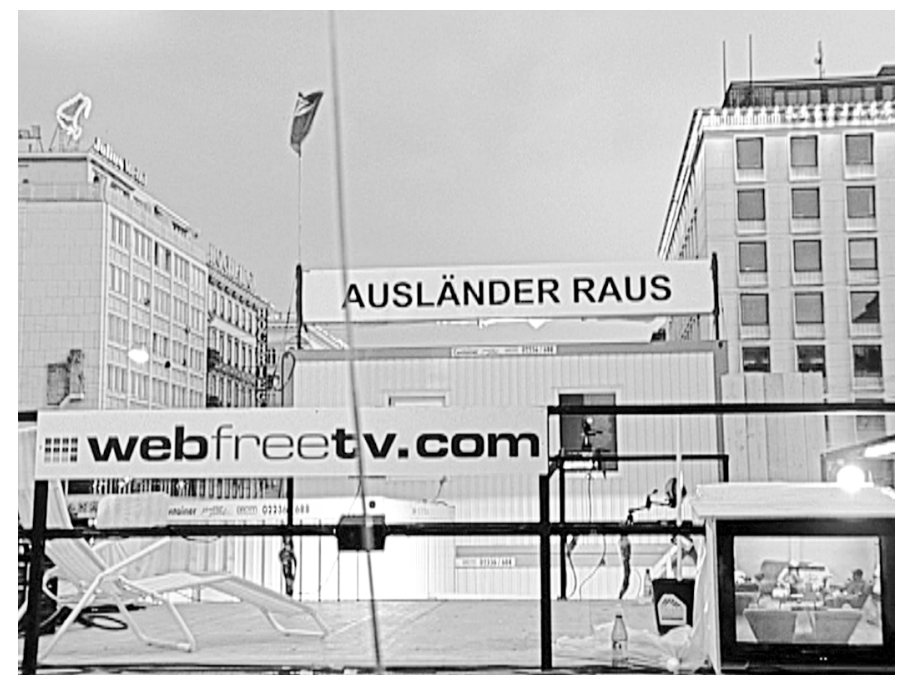

(c) Filmgalerie 451 and Paul Poet. 
Against the background of these developments and that same year, the German film and theatre director, author and performance artist Christoph Schlingensief initiated his container project, briefly alluded to earlier, which we will now examine in greater detail. The project, which was part of the Wiener Festwochen, was staged right in the heart of Vienna, in front of the State Opera on Herbert von Karajan Square. Here Schlingensief erected a container in 'Big Brother' style, confining 12 actual real-life refugees playacting as refugees inside it. After that he asked the population to decide by phone vote who could stay and who would be "ejected" from confinement and "deported" by security forces. The performance was shown livestream on the internet.

Incensed residents and members of the public, politicians and artists all had something to say. Their occasionally abstruse and perplexing public appearances and attacks on the container transformed Schlingensief's artistic engagement into a diffuse field. The artist had at times arranged to have himself doubled by actor André Wagner and then joined the scene as a representative of the FPÖ. He also frequently made use of statements by members of the public, proclaimed them loudly via megaphone, confirmed them or made them his own (Focke 2009: 40). There were also the 'celebrities of the day', including the German politician Gregor Gysi and the Austrian writer Elfriede Jelinek (Gilles 2009: 50-51).

Fig. 5.3: Schlingensief and actor André Wagner performing on top of one of the containers.

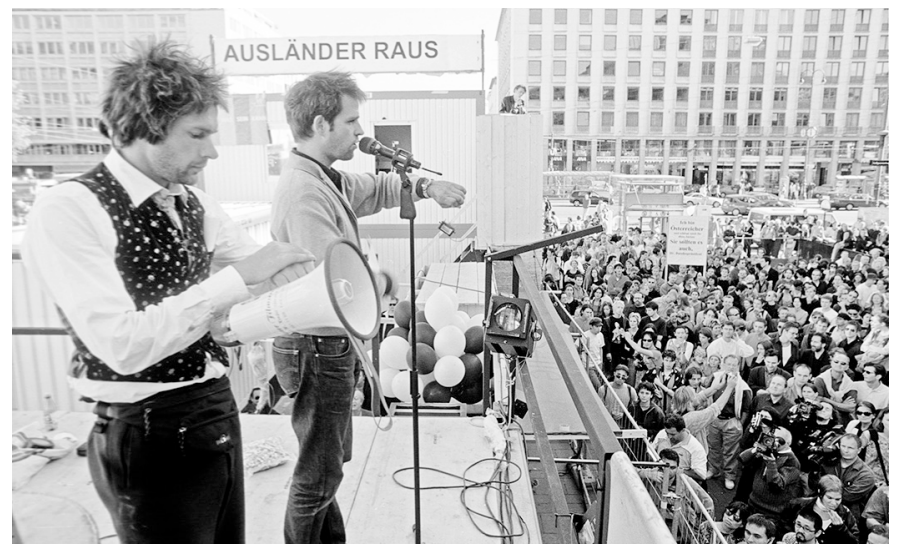

Photo by David Baltzer. @ David Baltzer/Bildbuehne.de

Given his double Wagner on the scene, the staging of quotes from members of the public and the 'celebrities of the day' - but also embroidered with music performances by bands like Einstürzende Neubauten and claims that it was actually a political campaign organised by the FPÖ and the Kronen Zeitung newspaper (Focke 
2009: 36) - it always remained unclear for outsiders whether the reactions to the performance were real or fictional. What was staged was constantly declared to be real, and what was real declared to be staged. This expressed itself symbolically in the double roles that all participants had willingly or unwillingly been allocated. Even the asylum-seekers in the container were real and yet at the same time playing the role of asylum-seekers, albeit with different biographies. The newspapers railed against the high costs of such an anti-Austrian campaign. Moreover, some tourists thought the performance was the implementation of an actual public initiative to arbitrarily deport as many refugees as possible. Subsequently, Schlingensief was either verbally attacked on television, completely ignored or even derided as politically corrupt, someone who had been 'bought and paid for'. With his political performance, the artist evidently managed to cause an uproar in politics and the general public. This suggests that a previously valid order of refugee discourse had been disrupted by the performance, thereby initiating a rupture in knowledge.

Fig. 5.4: Tourists passing by Schlingensief's containers.

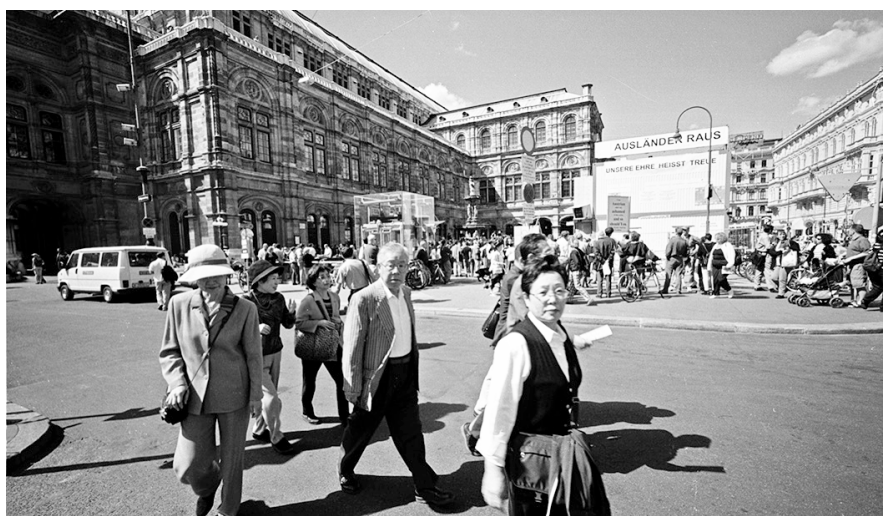

Photo by David Balzer. @ David Baltzer/Bildbuehne.de

Through his art performance, Schlingensief showed that such anti-migrant politics can be pursued with impunity, apparently everywhere and in every election campaign, openly expressing resentment and negativity towards refugees and asylum-seekers, but that it is undesirable to deliberately make people aware of this situation. Additionally, the performance exposed and highlighted the fact that people feel attacked when they are directly confronted, right in the heart of Vienna, with the dispositif of asylum. On an ORF radio show, Schlingensief described outraged reaction among some people as self-provocation; he stated that the performance revealed that the everyday racism amongst people had apparently been turned against themselves: 
Provocation is a tool for stupid people. This is a self-provocation. Here is an empty surface that they project their image onto, play their film upon. And they have the constant problem that the images turn against themselves. (Schlingensief in Lilienthal/Phillip 2000: 117)

Schlingensief's idea of self-provocation was elaborated on in greater detail by the journalist and art historian Mark Siemons (2000). According to Siemons, the effects of performance are based on ideas from system theory, which states that the actual diversity of people's real lives is barely represented in the dominant political system. Every attempt to transport everyday life into the dominant system must fail. If we apply this to the container performance, it means that Schlingensief's project should not only be seen as a left-wing, liberal statement about the practice of deporting refugees. Rather the project appeared much more to identify existing negative feelings about refugees and to engage and confront them actively. He used images from the media that are against 'foreigners' and even reproduced and strengthened them. Central thus was the utilisation of a whole flood of already existing right-wing populist imagery - and not a vocal criticism of right-wing populism, which would only have provoked a counter-rhetoric. It can be assumed that parties like the FPÖ and a politician such as Jörg Haider are immune to openly expressed disapproval of their asylum policy and prepared to react to such efforts, since this quasi is part of their everyday business as politicians (Siemons 2000: 125).

The performance unfolded as a kind of image-producing machine, in the process establishing a connection between the political and media orders. In this context, it is telling that the performance was clearly inspired by the paradigm of 'Big Brother' and that Schlingensief claimed to passers-by that the container was a joint project between the Kronen Zeitung newspaper and the FPÖ (Focke 2009: 36-37). The filmmaker Paul Poet directed the online broadcast of the container performance and in 2002 released his debut feature-length film of it, Ausländer Raus! Schlingensiefs Container (DVD 2006). The film shows not just the residents of the container, but also the visitors and passers-by in the broader public, all of them becoming a part of a media performance. In an interview, Paul Poet described the media attention that the art project provoked:

The followers on the internet ranged from Australian fan groups to Croatian skinhead gangs. Because the elimination game based on the Big Brother concept was pushed to its very limits by the performance on one hand and by reality on the other, the mask was torn off Austrian xenophobia. (Poet 2011: 460)

In order to be able to create this interplay between art and reality, fiction and truth, it was necessary to never fully reveal whether the people in the container were 
actors or not, and whether it was a political action. Additionally, according to Siemons, particular emphasis was laid on the aspect of emptiness - a vacant space in reality where people have the possibility to confront themselves and their own thinking. This emptiness became visible, for example, when demonstrators tore down the "Foreigners out" sign and desired to liberate the "container prisoners". According to Schlingensief, the demonstrators themselves were shocked about the fact that the asylum-seekers were real refugees (Siemons 2000: 127). In Schlingensief's performance, reality itself became a protest (Forrest 2015: 69). Thus, Schlingensief did not, as was claimed in the media, become a 'hired' provocateur.

The counter-hegemonial core of this action was mirrored in the outrage that fumed in reactions by members of the public, politicians, activists and representatives of the media. The asylum dispositifs, internalised in individuals' minds and mindsets, were called into question by the container. From Schlingensief's statement quoted above - namely that the container worked like an empty surface, onto which people projected their own image of something - we can conclude that he wished to induce the observers on the outside to "provoke themselves". This form of confrontation is at the least a means for generating awareness and reflection.

In addition, the performance evoked numerous different types of confusion. Numerous people viewed the 'refugee container' as 'real' and genuine, which is why signs and information leaflets had to be used to inform people of the artistic nature of the work. The grave uncertainty about whether the performance was art or not seems to support the assumption that racism is an integral part of social normality. Interestingly, others, such as participants in a demonstration organised by Viennese Antifa groups, opposed certain elements of the performance, such as destroying the sign mounted on the container that read "Foreigners out". Looking back, Schlingensief himself refers to the art performance in Vienna as a "tipping point":

I have touched these intersections of reality and fiction, of life and art, quite often before, not just during that week in Vienna. I sometimes thought I was dealing with reality but had to recognise that no one around me was taking the situation seriously. Or, at other times, I didn't take the situation seriously myself, and suddenly realised how serious and bitter it was. I've gone through these kinds of tipping points many times. Perhaps too many times. Because what I caused wasn't just unclear and contradictory for others. Often, I didn't know what exactly was going on either, which side of the line I was on at that given moment. (2014: 99)

Accordingly, Schlingensief took numerous "risks of resistance" (Scharathow 2014) with his container performance, provoking a miltitude of strong reactions in the city's public sphere. Among the main risks were in particular that he was personally devalued as an artist, that his action was represented as having been 'bought', 
and that the project did not simply contribute just to deconstructing but also to reproducing dispositifs of asylum.

In the research literature on cultural studies dealing with Christoph Schlingensief's art, his personal commitment and moral actions are described as the most essential elements of his performances, which as a rule take place live. It is therefore the 'live' contradictory situations beyond a fixed script that made the container performance so current and relevant, and also so unpredictable in how it would unfold. In the beginning was the concrete idea about how the conscious disruption of everyday life should be staged, but the action itself was based on the event-based nature of the discourse.

\section{Conclusion and prospects}

Historically shaped orders of knowledge flow into everyday discourses, political debates and pedagogical methods. In this sense, they are relevant to the way people act. Moreover, they shape "behaviour through official classifications and organisational routines" (Brubaker 2007: 43). In so doing, they frame individual and institutional spaces of action and possibilities, offering an interpretive knowledge that disburdens individuals, allowing them to identify with unambiguous perceptions of the world. These kinds of orders of knowledge, which Pierre Bourdieu in his theory of habitus has described as unquestioned, deeply-ingrained "doxic background convictions" - a system of the perception and evaluation of social relations of order that underpin the real and imagined world - take on a concentrated form in images and patterns of interpretation (Bourdieu 1982: 734-735). This is why we require approaches necessary in order to challenge these orders of knowledge, here in particular the asylum dispositif, and to take the phenomenon of migratory 'flight' and contemporary global "Human Flow" (Ai Weiwei 2017) as the point of departure for future analyses.

The postmigrant perspective constitutes a change of perspective, offering a different way of understanding the social spheres. It engages the predominant restrictive and generalising discourses on refugees and migration critically and supports a form of hands-on resistance against social hegemonies. "Postmigrant" in this context also means turning in opposition against a hegemonial historiography and production of knowledge, thereby bringing different historical and current connections to light (see esp. Yildiz 2017; Römhild 2017).

The Schlingensief performance with the refugee container in front of the $\mathrm{Vi}$ enna State Opera touched and moved people, angered them, or inspired them to reflect critically on their own prejudices and preconceptions. Forcefully engaging with this 'predetermined breaking point', the artist disrupted the power of the asylum dispositif, at least for a brief interval. In this way, the performance vehe- 
mently intervened in everyday routines - and thus also in the normality of the restrictive treatment of refugees in 'Fortress Europe'. The general public usually encounters the violent deportation of refugees carried out by EU member states with forms of "civil inattention" (Goffman 1963: 83), if not with total ignorance and cognitive repression. Rendering this situation visible - in a central space in Vienna where people from across the globe converge and Vienna presents itself and its picture postcard image to the outside world - inevitably creates a kind of potential tipping point. Schlingensief used the civil vulnerability of the place to draw attention to the exclusionary policies of border regimes. By choosing a central locus in the heart of Vienna, frequented daily by numerous tourists, Christoph Schlingensief managed to attract considerable attention with his artistic-political initiative. Quite specifically in an urban place that also functions as a key advert for Vienna, the city and its politicians are reluctant to be reminded of a concrete fact: that in their country, individuals are being deported due to their origin. It is singularly unpleasant for a city to display itself on one hand from an idyllic perspective - as a vibrant center of tourism - while on the other to be confronted with its own restrictive policy on asylum and refugees and its practices of expulsion. The vulnerability of the place thus hinges on the fact that everything happening there takes on a major significance - the venue of the container action in Vienna is centrally located, heavily frequented by roves of visitors. It is clearly in the observant eye of the public. Ultimately, the performance revealed in this manner that racism, to echo Mark Terkessidis, is an everyday phenomenon. Racism is not something that only occurs on the peripheries of society, for example in relation in the guise of neo-Nazis ready for violence; rather, it is an apparatus of power, a kind of knowledge that is produced right at society's centre, permanently transforming people into "strangers" (Terkessidis 2004).

From a postmigrant perspective, the performance in Vienna can be interpreted as an inversion of the hegemonial apparatus of power. "The banality of racism" (ibid.: 1), which reduces people to the figure of the refugee, was unexpectedly directed against passers-by in the broader public, who - as citizens of Vienna, of Austria or as citizens in general - were addressed and often felt attacked. Individuals found the container action disturbing, it caused confusion and led people to reflect on their sense of perplexity, while simultaneously looking for ways of dealing with their newly acquired knowledge. The film "Ausländer raus! Schlingensiefs Container" by Paul Poet (2006 [2002]) and the written documentation of the performance by Matthias Lilienthal and Claus Philipp (2000) visualise the broad palette of different aspects of how people reacted when they were confronted with the deportation of refugees: They reacted with ignorance, anger and defensiveness towards the performance.

What was unique about the container project was that it did not primarily focus on the knowledge of refugees, but rather engaged the knowledge of society. It 
was about people's experiences and their reactions to the informal confrontation with European practices of deportation and isolationist policies. The performance transformed the so-called 'refugee crisis' into a critical social analysis of nationalist mindsets and sensitivities. And by suspending binary patterns of thinking and social imaginaries, the performance also put forward a postmigrant perspective on the interrelations between different conceptualisations, making visible those forms of knowledge and practice that are rarely acknowledged in public discourse (Terkessidis 2017).

This contrapuntal perspective on flight, displacement and asylum offers a real chance to rethink existing patterns of social justice, democratising and reshaping the various institutions of the society, such as the education system, the labour and housing market, for the benefit of all who live here - enabling a fully novel discourse on society and societal conditions. What is germane here is not about jettisoning terms such as 'refugees' and 'migration'. Rather, they should be seen as important concepts capable of energising novel perspectives for social analysis in the global context.

Art performances like that of Christoph Schlingensief - which by representing the real as fictional and vice versa, disrupt or even nullify the discursive order of refugees and asylum - are able to expose racism as an everyday phenomenon, affecting all of society (Terkessidis 2004: 2017). By dint of its unpredictable progression as it unfolded, i.e. its event-based character as spectacle, the Vienna container performance generated a great deal of tension in the public and helped to deconstruct taboos about conventional refugee and asylum politics. By doing so, the performance identified racism as a problem in normal quotidian life in Austria; it made visible institutionalised practices of Othering predominant in the political sphere in Austria at the time, such as the tendency for media outlets to transform human beings into 'foreigners'. A subsequent step forward, following upon Schlingensief's art performance, would be to resolve to examine racism more continuously, exploring it as a general and longstanding problem in the society as a whole. Accordingly, this would constitute a task and challenge for the society as such: crucial is to focus on racism robustly over the long term, to constantly question and re-question exclusionary practices and logics. In this light, Schlingensief's container performance has provided a thought-provoking impulse for fresh perspectives, sparking new ways of thinking and active engagement.

\section{References}

Ai Weiwei (2017): “Ai Weiwei Discusses his Documentary 'Human Flow'. In: BUILD Series, October 6 (https://youtu.be/wEwjYb8P3YM). 
Althans, Birgit/Daryan, Nika/Sorgo, Gabriele/Zirfas, Jörg (2019): "Zwischen Flucht und Heimat. Einleitende Bemerkung zu einer Anthropologie der Bewegung”. In: Birgit Althans/Nika Daryan/Gabriele Sorgo/Jörg Zirfas (eds.), Flucht und Heimat. Sondierungen der pädagogischen Anthropologie, Weinheim/Basel: Beltz Juventa, pp. 7-24.

Bauman, Zygmunt (1997): Postmodernity and Its Discontents, Cambridge: Polity.

Bauman, Zygmunt (1998): Globalization: The Human Consequences, New York: Columbia University Press.

Beck, Ulrich (2017): Die Metamorphosen der Welt, Berlin: Suhrkamp.

Bhabha, Homi K. (1994): The Location of Culture, London: Routledge.

Bourdieu, Pierre (1982): Die feinen Unterschiede, Frankfurt a.M.: Suhrkamp.

Bourdieu, Pierre (1987): Sozialer Sinn. Kritik der theoretischen Vernunft, Frankfurt a.M.: Suhrkamp.

Bourdieu, Pierre/Wacquant, Loïc J. D. (1992): An Invitation to Reflexive Anthropology, Chicago: The University of Chicago Press.

Brubaker, Roger (2007): Ethnizität ohne Gruppen, Hamburg: Hamburger Edition. Ette, Andreas (2017): Migration and Refugee Policies in Germany: New European Limits of Control? Opladen/Berlin/Toronto: Barbara Budrich.

Eurostat (2018): "Asyl in den EU-Mitgliedstaaten". In: Press Release 47/2018, March 20 (https://ec.europa.eu/eurostat/documents/2995521/8754393/3-20032018-APDE.pdf/72fe7d90-d966-425a-832f-28dc3a4cd2e6).

Focke, Ann-Christin (2009): "Zum Verhältnis von Mensch und Ordnung im Rahmen einer affirmativen politischen Theaterästhetik am Beispiel von Schlingensiefs Bitte liebt Österreich - Erste europäische Koalitionswoche (Ausländerraus)". In: Forum Modernes Theater 24/1, pp. 31-47.

Forrest, Tara (2015): Realism as Protest. Kluge, Schlingensief, Haneke, Bielefeld: transcript.

Foucault, Michel (1980): Power/Knowledge: Selected Interviews and Other Writings, 1972-1977, edited by Colin Gordon, New York: Pantheon Books.

Friese, Heidrun (2017): Flüchtlinge. Opfer - Bedrohung - Helden. Zur politischen Imagination des Fremden, Bielefeld: transcript.

Gilles, Catharina (2009): Kunst und Nichtkunst. Das Theater von Christoph Schlingensief, Würzburg: Königshausen \& Neumann.

Goffman, Erving (1961): Asylums: Essays on the Social Situation of Mental Patients and Other Inmates. Garden City/NJ: Anchor Books.

Goffman, Erving (1963): Behavior in Public Places: Notes on the Social Organization of Gatherings, New York: The Free Press.

Hall, Stuart (1992): “The West and the Rest: Power and Discourse”. In: Stuart Hall/ Bram Gieben (eds.), Formations of Modernity, Cambridge: Polity Press, Blackwell and The Open University, pp. 275-331. 
Hall, Stuart (1996): "When was the 'post-colonial?' Thinking at the limit". In: Iain Chambers/Lidia Curti (eds.), The Post-colonial Question: Common Skies, Divided Horizons, London and New York: Routledge, pp. 242-260.

Haslinger, Josef (2016): “Die staatlichen Egoismen”. In: Gerfried Sperl (ed.), Flüchtlinge. Phoenix - Essays, Diskurse, Reportagen, vol. 2, Vienna: Czernin, pp. 1523.

Hess, Sabine (2015): "Politiken der (Un-)Sichtbarmachung. Eine Kritik der Wissens- und Bilderproduktion zu Migration". In: Erol Yildiz/Marc Hill (eds.), Nach der Migration. Postmigrantische Perspektiven jenseits der Parallelgesellschaft, Bielefeld: transcript, pp. 49-64.

Hill, Marc. 2019. "Europa retten? Agency in der Migrationsgesellschaft". In: Soziale Arbeit 68/8, pp. 302-308.

Inhetveen, Katharina (2010): "Der Flüchtling”. In: Stephan Moebius/Markus Schroer (eds.), Diven, Hacker, Spekulanten. Sozialfiguren der Gegenwart, Berlin: Suhrkamp, pp. 148-160.

Lilienthal, Matthias/Philipp, Claus (2000): Schlingensiefs Ausländer raus, Frankfurt a.M.: Suhrkamp.

Ottomeyer, Klaus (2009): Jörg Haider. Mythenbildung und Erbschaft, Klagenfurt/ Celovec: Drava.

Park, Robert E (1928): "Human Migration and the Marginal Man". In: The American Journal of Sociology 33/6, pp. 881-893.

Poet, Paul (2006 [2002]): Ausländer raus! Schlingensiefs Container, Austria: Bonus Film GmbH, HOANZL/Ö-Film/Edition Der Standard, version: DVD 2006, 90 minutes (https://vimeo.com/ondemand/auslaenderraus2002).

Poet, Paul (2011): "Paul Poet im Gespräch mit Christoph Kepplinger". In: Pia Janke/Teresa Kovacs (eds.), Der Gesamtkünstler Christoph Schlingensief, Vienna: Praesens, pp. 460-464.

Römhild, Regina (2017): "Beyond the bounds of the ethnic: For postmigrant cultural and social research". In: Journal of Aesthetics and Culture 9/2, pp. 69-75 (https://www.tandfonline.com/doi/full/10.1080/20004214.2017.1379850).

Said, Edward W. (1994): Culture and Imperialism, London: Chatto and Windus.

Sassen, Saskia (1996): Migranten, Siedler, Flüchtlinge. Von der Massenauswanderung zur Festung Europa, Frankfurt a.M.: Fischer.

Scharathow, Wiebke (2014): Risiken des Widerstandes. Jugendliche und ihre Rassismuserfahrungen, Bielefeld: transcript.

Scherr, Albert (2017): "Die Abschwächung moralischer Empörung. Eine Analyse politischer Reaktionen auf zivilgesellschaftliche Proteste gegen Gesetzesverschärfungen und Abschiebungen”. In: Z'Flucht. Zeitschrift für Flüchtlingsforschung $1 / 1$, pp. 88-105.

Schlingensief, Christoph (2014): Ich weiss, ich war's, Cologne: Kiepenheuer \& Witsch. 
Seukwa, Louis Henri (2015): "Flüchtlinge: Von der Kunst des Überlebens”. January 5 (https://www.dkjs.de/aktuell/meldung/news/fluechtlinge-von-der-kunstdes-ueberlebens).

Seukwa, Louis Henri (2006): Der Habitus der Überlebenskunst. Zum Verhältnis von Kompetenz und Migration im Spiegel von Flüchtlingsbiographien, Münster: Waxmann.

Siemons, Mark (2000): "Der Augenblick, in dem sich das Reale zeigt. Über die Selbstprovokation und die Leere". In: Matthias Lilienthal/Claus Philipp (eds.), Schlingensiefs Ausländer raus, Frankfurt a.M.: Suhrkamp, pp. 120-127.

Terkessidis, Mark (2004): Die Banalität des Rassismus. Migranten zweiter Generation entwickeln eine neue Perspektive, Bielefeld: transcript.

Terkessidis, Mark (2017): Nach der Flucht. Neue Ideen für die Einwanderungsgesellschaft, Ditzingen: Reclam.

UNHCR The UN Refugee Agency (2018): "Global Trends: Forced Displacement in 2017" (https://www.unhcr.org/dach/wp-content/uploads/sites/27/2018/06/ GlobalTrends2017.pdf).

United Nations/General Assembly (2018): "Zwischenstaatliche Konferenz zur Annahme des Globalen Paktes für eine sichere, geordnete und reguläre Migration" (https://www.un.org/depts/german/migration/A.CONF.231.3.pdf).

Yildiz, Erol (2006): "Stigmatisierende Mediendiskurse in der kosmopolitanen Einwanderungsgesellschaft". In: Christoph Butterwegge/Gudrun Hentges (eds.), Massenmedien, Migration und Integration, Wiesbaden: VS Verlag für Sozialwissenschaften, pp. 35-53.

Yildiz, Erol (2017): "Postmigrantische Migrationsforschung”. In: Lena Karasz (ed.), Migration und die Macht der Forschung. Kritische Wissenschaft in der Migrationsgesellschaft, Vienna: ÖGB, pp. 11-22. 